\title{
THE IMPACT OF HYPNOTEACHING LEARNING METHODS ON STUDENTS' BIOLOGY ACHIEVEMENT IN MIA GRADE IX SENIOR HIGH SCHOOL 1 GOWA
}

\author{
Ulfa Alfiani Ahmad ${ }^{1}$ \\ Hilmi Hambali ${ }^{2 *}$ \\ Anisa $^{3}$ \\ 1,2,3Prodi Pendidikan Biologi Universitas Muhammadiyah Makassar, Indonesia \\ ulfalfiani97@gmail.com ${ }^{1)}$ \\ hilmihambali@unismuh.ac.id ${ }^{2}$ ) \\ anisa@unimuh.ac.id ${ }^{3)}$
}

\begin{abstract}
Abstrack
This study aims to determine the learning outcomes of MIA XI grade students of SMA Negeri 1 Gowa on Biology subjects taught using hypnoteaching learning methods and Quasi experimental research type with nonequivalent control group design. The research instruments used were tests, questionnaires, and observation sheets. Data processing is done by descriptive statistical analysis and inferential statistical analysis. The variables studied in this study were the application of hypnoteaching learning methods and learning outcomes. The results of the data analysis showed the application of hypnoteaching learning methods to student learning outcomes. This is indicated by the difference between student learning outcomes taught by using the Hypnoteaching learning method and student learning outcomes not taught by using the Hypnoteaching learning method in the control class and the experimental class. This is reviewed based on a comparison of the final learning outcomes of the experimental class, namely an increase in the average score of 33.74 to an average score of 87.60. Based on the data obtained it can be concluded that the Hypnoteaching learning method can improve student learning outcomes in Biology subjects. The results of inferential statistical analysis using covariance analysis obtained a Sig. calculate value $(0.000)<\alpha(0.05)$ which shows that $\mathrm{H}_{0}$ is rejected and $\mathrm{H}_{1}$ is accepted. Thus, it can be stated that there is a very significant difference between student learning outcomes in the control class and the experimental class.
\end{abstract}

Keywords: Hypnoteaching Method, Learning Outcomes

Published by:

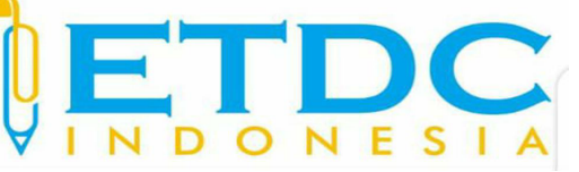

Copyright (C) 2021 The Author (s)

This article is licensed under CC BY 4.0 License

(cc) $\mathrm{BY}$ 


\section{THE IMPACT OF HYPNOTEACHING LEARNING METHODS ON STUDENTS' BIOLOGY ACHIEVEMENT IN MIA GRADE IX SENIOR HIGH SCHOOL 1 GOWA}

\section{Introduction}

The education component should look far ahead and think about what learners will face. One of the main problems in learning in formal education (school) today is the low absorption of learners in receiving subject matter that affects student achievement. This achievement is certainly the result of learning conditions that are still conventional and do not touch the realm of the dimension of the student's own achievement, namely how they are actually learning it. In a substantial sense, the learning process to this day still gives teacher dominance and less access for learners to develop independently through discovery and thought processes.

Biological learning requires many appropriate learning methods and can involve students as optimally as possible, both intellectually and emotionally. So that students or learners better understand clearly and are not impressed abstractly with what is learned in the classroom, because biology lessons emphasize process skills and because biology is a science that is often found in everyday life. Through biology lessons, students are expected to develop their scientific thinking patterns that include an honest, and objective attitude towards facts and an ever-evolving inquisitive attitude, that can then be applied in everyday life in society.

If you look at the implementation of learning in the classroom, the use of varied learning methods is still very low and teachers tend to use lecture methods, and reduce students' interest in every teaching and learning activity carried out. This may be due to a lack of mastery of learning methods that are indispensable to improving the professional ability of teachers and the absorption of learning materials by students. In addition, low student learning outcomes are seen in most students who get grades below KKM, which is below the minimum completion criteria with a value weight of 75 , students who achieve KKM scores only $50 \%$ of the total. To get the expected learning results, it needs serious handling and thinking. Because each student as a different individual, they require a different way to receive the material delivered.

Lestari (2010) states that the hypnolearning learning model can increase student learning activities that affect student learning outcomes. This is due to the increasing enthusiasm of students because Hypnolearning is a unique, creative, and imaginative way of teaching. This is followed by increased student learning outcomes. The application of Hypnoteaching learning methods in Biology learning can create an effective and enjoyable learning atmosphere for students. Biology learning will not cause students distress, anxious 
feelings and students to fear the problems given by teachers with persuasive positive suggestions. Hypnoteaching makes the relationship between teachers and students compact and dynamic so that the teaching and learning process in the classroom becomes livelier and more effective. In line with Hamidah's statement (2016) which states that based on the results of data analysis and discussion on the use of Hypnoteaching methods to increase student motivation and liveliness, it can be concluded that hypnoteaching methods can improve students' motivation, liveliness, and science process skills. This is followed by increased student learning outcomes.

One learning method that can improve learning outcomes is the Hypnoteaching method. This reason is reinforced by the results of research conducted by Kasmaja (2016) which states that the increase in learning motivation is born from a learning process using hypnoteaching methods with a contextual approach, so that students easily understand the material if given contextual examples by associating the material with the everyday environment.

Based on the description, the purpose of this study is to determine the influence of Hypnoteaching learning methods on the biological learning outcomes of MIA XI state high school students. The hypothesis in this study is that there is an influence of Hypnoteaching learning methods on student learning outcomes in the biology learning class MIA XI State High School 1 Gowa.

\section{Method}

This type of research is experimental research with a research design basee on a nonEquivalent control droup Design. The population in this study was all MIA students of State High School 1 Gowa, which amounted to 201 students. The study sample used purposive sampling techniques with MIA CLASS XI 5 (experiment) and MIA XI 6 (control).

The free variables in this study in the form of Hypnoteaching (X) and Bound Variable (Y) learning methods in this study were the learning outcomes of students of MIA XI State High School 1 Gowa. In this study, researchers used research instruments in the form of Pretest and posttest with essay-shaped problems as many as 10 questions. The data collection technique used by researchers is in a gradual way, namely by giving pretest and posttest. The data analysis techniques used are descriptive statistical analysis and inferential statistics on pretest and posttest data in experimental and control classes. 


\section{Results and Discussions}

\subsection{Descriptive Statistical Analysis}

Here is descriptive statistical analysis data of learners' biological learning outcomes in control classes and experiments:

Table 1. Statistical Analysis Data Score Results of Biological Learning Students Control and Experiments

\begin{tabular}{|c|c|c|c|c|}
\hline \multirow[t]{2}{*}{ Statistics } & \multicolumn{2}{|c|}{ Control Class } & \multicolumn{2}{|c|}{ Experiment Class } \\
\hline & pretest & postest & pretest & postest \\
\hline $\begin{array}{l}\text { Number of } \\
\text { students }\end{array}$ & 33 & 33 & 35 & 35 \\
\hline Lowest value & 9 & 64 & 11 & 76 \\
\hline Highest value & 55 & 87 & 58 & 100 \\
\hline Average & 29,06 & 77,45 & 33,74 & 87,60 \\
\hline $\begin{array}{l}\text { Standard } \\
\text { deviation }\end{array}$ & 11,39 & 5,40 & 14,03 & 8,02 \\
\hline
\end{tabular}

Table 2. Student Biology Study Outcome Score Category

\begin{tabular}{lccccc}
\hline \multirow{2}{*}{ Interval } & Category & \multicolumn{2}{c}{ Control Class $(\%)$} & \multicolumn{2}{c}{ Experiment Class $(\%)$} \\
\cline { 3 - 6 } & & pretest & postest & pretest & postest \\
\hline $93-100$ & Very good & 0 & 0 & 0 & 31,43 \\
$84-92$ & Good & 0 & 18,18 & 0 & 40 \\
$75-83$ & Enough & 0 & 57,58 & 0 & 28,57 \\
$<75$ & Low & 100 & 24,24 & 100 & 100 \\
\hline
\end{tabular}

Can be seen from Tabel 2 the number of learners in the experimental class who obtained learning results in the excellent category is $31.43 \%$, the good category $40 \%$, the category is quite $28.57 \%$ and $0 \%$ in the lesser category.

Table 3. N-Gain Test Results

\begin{tabular}{|c|c|c|c|c|c|c|c|c|}
\hline & \multicolumn{4}{|c|}{ Control Class } & \multicolumn{4}{|c|}{ Experiment Class } \\
\hline & Pretest & $\begin{array}{c}\text { Post- } \\
\text { test }\end{array}$ & $\begin{array}{c}\text { N- } \\
\text { Gain }\end{array}$ & Category & Pretest & $\begin{array}{c}\text { Post- } \\
\text { test }\end{array}$ & N-Gain & Category \\
\hline $\begin{array}{l}\text { Number } \\
\text { of } \\
\text { students }\end{array}$ & \multicolumn{4}{|c|}{33 students } & \multicolumn{4}{|c|}{35 students } \\
\hline $\begin{array}{l}\text { Average } \\
\text { value }\end{array}$ & 29,06 & 77,45 & 0,67 & Medium & 33,74 & 87,60 & 0,80 & High \\
\hline
\end{tabular}

Based on Tabel 3 above it is seen that the average value of N-Gain test scores of learners' learning outcomes in the experimental group of 0.80 is categorized as high, while in the control group of 0.67 which is in the moderate category. 


\subsection{Inferential Analysis}

Prerequisite test results, namely the normality and homogeneity test, based on the results of data analysis using statistics SPSS 25 normality test (Kolmogrov-Smirnov) and homogeneity test (Homogenity of variance Test) obtained normal and homogeneous distribution results, while independent samples t Test obtained significance value of 0.000 where the value of significance is less than the significance level value of $0.05(0.001 \leq 0.05)$. Thus, $\mathrm{H}_{0}$ is rejected and $\mathrm{H}_{1}$ is accepted so it can be said that there is an influence of Hypnoteaching learning methods on the biological learning outcomes of mia XI state high school students gowa.

Based on the results of the data analysis outlined above, quantitatively the results of this experimental study showed a significant difference in learning outcomes between control classes and experimental classes in the learning process using conventional learning methods and Hypnoteaching learning methods in students of class XI MIA State High School 1 Gowa.

This shows that the application of Hypnoteaching learning methods can increase the average student's grades and be able to increase the number of students who fall into the category of excellent mastery levels. This is in line with the results of research conducted by Fitria Prabandari (2009) which states that the application of Hypnoteaching learning methods can improve student learning outcomes, because hypnoteaching learning methods lead more to the psychological readiness of the child, therefore Hypnoteaching Applied in the teaching and learning process aims to form the psychological readiness of a child before receiving various responses from outside the child.

The low average grade of student learning outcomes in the control class is due to teachers teaching with non-varied methods whose effects make students not involved as a whole and sometimes there are still many teachers who pay less attention to the psychological level of the students themselves. Because by one word that is learning, which is learning is like an imposition to everyone to follow it and not only that, if the word learning is replaced with the word training or course then the brain will generalize and equate it with learning.

Still the person who follows him becomes a reluctant or lazy person to pay attention to the teacher so as to make the student conceptualist. The impact of students is often not enthusiastic in taking lessons. Students are difficult to manage because they feel the teacher is not paying attention to it. In addition, students are also difficult to focus and difficult to understand. Another impact is that students like to ditching. The problem is for fear of facing lessons that are considered boring. Thus, it can be concluded that there is a significant difference between the learning outcomes of biology students are taught with the application of hypnoteaching learning methods and students who are taught without the application of such 
methods.

The implementation of the learning process can be seen from the activities that have been carried out by teachers by implementing hypnoteaching method steps in learning. Hypnoteaching method learning is effective enough to be applied to improve student learning outcomes. This statement is in line with research conducted by Kasmaja (2016). This suggests that hypnoteaching learning methods are very effectively applied to the learning process.

\section{Conclusion}

Based on the results of research and discussions that have been outlined, it can be concluded that there is an influence on the learning outcomes of students of MIA XI State High School 1 Gowa by applying hypnoteachinglearningmethods. This has been proven on the hypothesis test using the Independent Sample T-test in which a significant grade of student learning outcomes is $0.000<0.05$.

Furthermore, researchers are expected to try to find the influence of hypnoteaching methods on variables other than learning outcomes so that this method can be more widely used so that it is beneficial for the improvement of learning quality in the classroom

\section{REFERENCE}

Darmadi. (2017). Pengembangan Model dan Metode Pembelajaran dalam Dinamika Belajar Siswa. Yogyakarta. Deepublish.

Fathurrohman P, Sobry S. (2010). Strategi Belajar dan Mengajar. Bandung. Refika Utama.

Hamidah N, Sawitri K. (2016). Penggunaan Hypnoteaching untuk Meningkatkan Motivasi dan Keaktifan Siswa. Jurnal biologi dan pembelajaran biologi. Volume 1 Nomor 1. p-ISSN: 2527-7111 e-ISSN: 2528-1615.

Hasbullah, Rahmawati E. (2015). Pengaruh Penerapan Metode Hypnoteaching terhadap Motivasi Belajar Mahasiswa Universitas Indraprasta PGRI. Jurnal formatif. Volume 5 Nomor 1 hal. 83-90. ISSN: 2088-351X.

Kasmaja, Hadi. (2016). Efektivitas Implementasi Metode Hypnoteaching untuk Meningkatkan Motivasi dan Hasil Belajar Matematika pada Siswa SMP Negeri. Jurnal of EST, Volume 2 Nomor 1 April 2016 hal. 33-45. P-ISSN: 2460-1407 e-ISSN: 2477-3840.

Kemendikbud. (2014). Permendikbud No. 59 tentang Kerangka Dasar dan Struktur Kurikulum Sekolah Menengah Atas / Madrasah Aliyah. Jakarta: Kementrian Pendidikan dan Kebudayaan.

Kusuma, dkk. (2016). Menjadi Guru Hebat dengan Hypnoteaching. Jakarta. Kata Pena. 
Lestari, Sri Rezki Nur. (2010). Pengaruh Model Pembelajaran Hypnolearning terhadap Hasil Belajar Biologi Siswa Kelas XI IPA SMA Negeri 1 Sungguminasa Kabupaten Gowa. Skripsi. Universitas Islam Negeri Alauddin Makasar.

Sugiyono. (2017). Metode Penelitian Kuantitatif, Kualitatif dan R\&D. Bandung. Alfabeta.

Susanto, Ahmad. (2016). Teori Belajar dan Pembelajaran di Sekolah Dasar. Jakarta. Kencana. 